\title{
Late Holocene Pollen Stratigraphy in Four Northeastern United States Lakes
}

\section{La stratigraphie pollinique de quatre lacs du nord-est des États-Unis à l'Holocène supérieur Pollen-Stratigraphie im späten Holozän in vier Seen Nordosten der Vereinigten Staaten}

\author{
K. Gajewski, A. M. Swain et G. M. Peterson
}

Volume 41, numéro 3, 1987

URI : https://id.erudit.org/iderudit/032693ar

DOI : https://doi.org/10.7202/032693ar

Aller au sommaire du numéro

Éditeur(s)

Les Presses de l'Université de Montréal

ISSN

0705-7199 (imprimé)

1492-143X (numérique)

Découvrir la revue

Citer cet article

Gajewski, K., Swain, A. M. \& Peterson, G. M. (1987). Late Holocene Pollen Stratigraphy in Four Northeastern United States Lakes. Géographie physique et Quaternaire, 41(3), 377-386. https://doi.org/10.7202/032693ar
Résumé de l'article

Quatre diagrammes polliniques des états du Maine, de New York et de Pennsylvanie illustrent de manière détaillée (40 ou 80 ans) les changements survenus dans la végétation du nord-est des États-Unis sur une période de 2000 ans. Les trois diagrammes des états du Maine et de New York enregistrent un accroissement continu de l'influx pollinique (PAR) de Picea. Il y a environ 1100 ans, Tsuga et Fagus ont subi une diminution, tandis que Quercus et Castanea ont augmenté à Ely Lake, dans le nord-est de la Pennsylvanie. Il y a 500 ans, Tsuga et Fagus ont considérablement diminué dans les états du Maine et de New York, alors que leur représentation pollinique augmentait dans le nord-est de la Pennsylvanie et que Quercus et Castanea diminuaient. Les influx polliniques des herbacés étaient minimes avant l'arrivée des Européens dans la région, après quoi ces taxons ont connu une augmentation subite. 


\section{LATE HOLOCENE POLLEN STRATIGRAPHY IN FOUR NORTHEASTERN UNITED STATES LAKES}

K. GAJEWSKI ${ }^{\star}$, A.M. SWAIN, and G.M. PETERSON ${ }^{\star}$, Center for Climatic Research, Institute for Environmental Studies, University of Wisconsin-Madison, Madison, Wisconsin 53706, U.S.A.

ABSTRACT Four pollen diagrams from Maine, New York, and Pennsylvania provide fine resolution (40 or 80 years) records of vegetation change in northeastern United States during the past 2000 years. A long term increase in pollen accumulation rates (PAR) of Picea occurred at the three sites in Maine and New York. Around 1100 years ago, Tsuga and Fagus decreased and Quercus and Castanea increased at Ely Lake in northeastern Pennsylvania. Around 500 years ago, Tsuga and Fagus greatly decreased in Maine and northern New York, while in northeastern Pennsylvania there was an increase in Tsuga and Fagus and a decrease in Quercus and Castanea pollen. Non-arboreal PAR were negligible prior to the European settlement of the area, after which there was an abrupt increase in non-arboreal pollen types.
RÉSUMÉ La stratigraphie pollinique de quatre lacs du nord-est des États-Unis à l'Holocène supérieur. Quatre diagrammes polliniques des états du Maine, de New York et de Pennsylvanie illustrent de manière détaillée (40 ou 80 ans) les changements survenus dans la végétation du nord-est des États-Unis sur une période de 2000 ans. Les trois diagrammes des états du Maine et de New York enregistrent un accroissement continu de l'influx pollinique (PAR) de Picea. II y a environ 1100 ans, Tsuga et Fagus ont subi une diminution, tandis que Quercus et Castanea ont augmenté à Ely Lake, dans le nord-est de la Pennsylvanie. II y a 500 ans, Tsuga et Fagus ont considérablement diminué dans les états du Maine et de New York, alors que leur représentation pollinique augmentait dans le nord-est de la Pennsylvanie et que Quercus et Castanea diminuaient. Les influx polliniques des herbacés étaient minimes avant l'arrivée des Européens dans la région, après quoi ces taxons ont connu une augmentation subite.
ZUSAMMENFASSUNG Pollen-Stratigraphie im späten Holozän in vier Seen Nordosten der Vereinigten Staaten. Vier PollenDiagramme von Maine, New York und Pennsylvania geben detaillierte Auflösungs-Nachweise der Vegetationswechsel im Nordosten der Vereinigten Staaten während der letzten 2000 Jahre. Ein langfristiges Anwachsen der Pollen-Akkumulationsraten (PAR) von Picea trat an den drei Fundstellen in Maine und im Staat New York auf. Vor ungefähr 11000 Jahren, nahmen am Ely-See in Nordost-Pennsylvania Tsuga and Fagus ab und Quercus und Castanea zu. Vor ungefähr 500 Jahren nahmen in Maine und im Norden des staats New York Tsuga und Fagus stark ab. während in Nordost-Pennsylvania Tsuga und Fagus zunahmen und Quercus und Castanea-Pollen abnahmen. Die nicht von Bäumen stammenden PAR waren gering, bevor das Gebiet von Europäern besiedelt wurde, während danach die nicht von Bäumen stammenden Pollenarten plötzlich anwuchsen.

\footnotetext{
* Present address: Division of Life Sciences, Scarborough College, 1265 Military Trail, Scarborough, Ontario M1C 1A4.

** Present address: 350 Kent Lane, \#101, Madison, Wisconsin 53713, U.S.A.
} 


\section{INTRODUCTION}

Late Holocene pollen diagrams from northeastern United States and southeastern Canada show an increase in Picea and other boreal forest pollen types and a decrease in Tsuga and hardwood types (BERNABO and WEBB, 1977 ; DAVIS, 1983; DAVIS et al., 1980; DAVIS et al., 1975; GAUDREAU and WEBB, 1985 ; LIKENS and DAVIS, 1975 ; MOTT, 1975, 1977 ; RICHARD, 1977). Between 2000 years $\mathrm{BP}$ and the present, the area of abundant Tsuga and Fagus pollen percentages decreased both in northern New England and southeastern Canada and in southern New England and northern Pennsylvania; this was the result of the increase in Picea in the north and at least partly due to anthropogenic activities to the south (GAUDREAU and WEBB, 1985). In southern New England, Quercus pollen decreased and Castanea first appeared in the pollen record in the past 2000 years (DAVIS, 1969 ; GAUDREAU and WEBB, 1985 ; WHITEHEAD, 1979). Few other large-scale patterns can be detected either from individual pollen diagrams or from mapped changes in pollen percentages (BERNABO and WEBB, 1977 ; GAUDREAU and WEBB, 1985).

Most pollen diagrams have little detail in the late Holocene and resolve only long term changes in vegetation formations. Dating of the sediment sequences is usually based on extrapolation from a few radiocarbon dates, which puts a limit on the temporal scale of events in the pollen record that can be correlated between sites. Sequences of maps showing the spatial patterns of pollen deposition at the beginning and end of this time period (e.g. GAUDREAU and WEBB, 1985) do not indicate the rates of vegetation changes. Four pollen records from lakes with varved sediments (Fig. 1) were obtained to show in detail the sequence of vegetation change in northeastern United States for the past 2000 years.

The overall pattern of vegetation in the study area (Fig. 1; BARRETT, 1980 ; LULL, 1968 ; WESTVELD, 1956) ranges from an area of predominantly spruce-fir forest type in the northeast to an area of oak-hickory forest type in the south. Between these northern and southern forest types is a broad zone consisting of northern hardwood and hemlock - white pine - northern hardwoods forest types.

At each coring site the vegetation varies in more detail than can be shown on Figure 1. In northern Maine (Conroy Lake) spruce-fir forest type (which includes Picea glauca, $P$. rubens, and Abies balsamea) is predominant, with northern hardwoods forest type (Fagus grandifolia, Betula lutea, and Acer saccharum) more abundant on mesic sites (OOSTING and REED, 1944). In southern Maine (Basin Pond), northern hardwoods are regionally important (Fig. 1), with Pinus strobus more abundant on coarser soils (BARRETT, 1980) or after disturbance. In northern New York (Clear Pond), sprucefir forests are dominant at higher elevations in the Adirondack Mountains, while hemlock-hardwood forests increase in abundance to the south. In northeastern Pennsylvania (Ely Lake) the northern hardwoods are more important in more mesic sites, while Quercus becomes more abundant

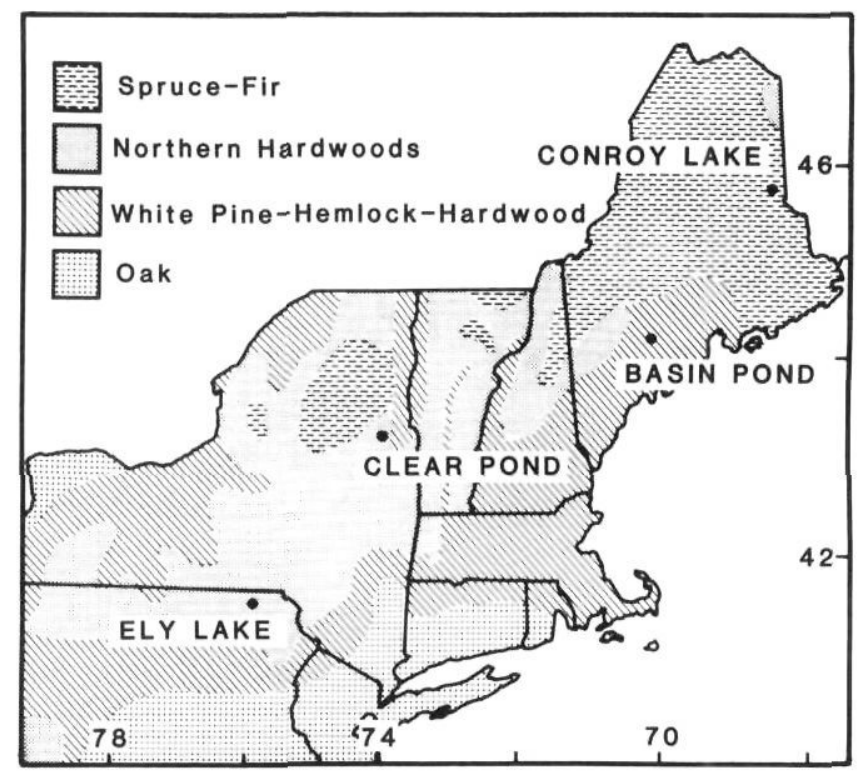

FIGURE 1. Location of lakes in northeastern United States. Forest types after LULL, 1968.

Localisation des lacs échantillonés dans le nord-est des États-Unis. Identification des types de forêts selon LULL, 1968.

on drier sites (BARRETT, 1980). None of the lakes has bogs on the periphery.

\section{METHODS}

Sediment cores were collected from the deepest portion of each lake (by A. Swain and R. Steventon) using a $5 \mathrm{~cm}$ diameter freezing corer (SWAIN, 1973; WRIGHT, 1980). The sediment was stored frozen until analyzed and varves were counted on the frozen cores. The cores were marked off at ten year intervals and the width of the ten-year sections was measured using a cathetometer. Strips of the measured frozen sediment were removed to obtain subsamples for pollen analysis. Inspection of these strips showed minimal deformation of the laminations due to the penetration of the corer. For the cores from Ely Lake and Clear Pond, the sediment was placed in Carbowax and the hardened sediment was trimmed to a measured volume, after SWAIN (1978). For the cores from Basin Pond and Conroy Lake, the sediment was melted to room temperature and then was measured in a $0.5 \mathrm{ml}$ calibrated spoon. The subsamples were all similarly processed using standard methods (FAEGRI and IVERSEN, 1975), including $10 \% \mathrm{KOH}, 10 \% \mathrm{HCl}$, concentrated $\mathrm{HF}$ and acetolysis solution. The stained residue was mounted in silicone oil. Eucalyptus tablets were added to the sediment prior to processing to enable the calculation of pollen concentration (see MAHER, 1981), and the measurements of the sediment thickness enabled the computation of pollen accumulation rates. A discussion of the confidence limits of the pollen accumulation rates derived using these methods can be found in GAJEWSKI et al., (1985). The pollen sum consists of at least 300 grains/level. Counts range between 300 and 480 grains, with an overall mean of approximately 350 grains/level. 


\section{RESULTS}

In the remainder of this paper, reference to pollen amounts will indicate pollen accumulation rates (PAR; influx, pollen deposition rates) unless specifically stated otherwise. In all four pollen diagrams discussed in this paper, PAR is constant at roughly $10000 \mathrm{grains} / \mathrm{cm}^{2} / \mathrm{yr}$ (GAJEWSKI, 1983), and thus the diagrams can be easily compared to percentage pollen diagrams.

\section{CONROY LAKE}

The Conroy Lake pollen accumulation rate diagram (Fig. 2) covers the past 1970 years. As described in Appendix I, a dating correction has been applied to the upper 150 years. All identified pollen grains are used to create the pollen diagram, although several rare types are aggregated in the categories "Other Trees and Shrubs" and "Other Herbs". PAR of several of the uncommon taxa which are included on some, but not all, of the pollen diagrams are listed in Table I. Tables of all of the taxa included in these two categories, as well as tables of the pollen percentages are available from the authors.

Zone I ( 1970 to 500 years ago) was characterized by low, but increasing amounts of Picea pollen. Pinus strobus pollen varied between 500 and 2000 grains $/ \mathrm{cm}^{2} / \mathrm{yr}$ with relative mimima centered around 800 and 1300 years ago. Tsuga pollen was relatively abundant in this zone, except for the time around 1800 years ago, when the accumulation rate decreased to less than 500 grains $/ \mathrm{cm}^{2} / \mathrm{yr}$. Beginning around 900 years ago, Tsuga pollen steadily declined. Betula pollen increased slightly from 2000 to 1700 years ago, remained at high values until 1200 years ago and subsequently decreased between 1100 and 500 years ago. Other hardwoods, such as Fagus, Acer, Ostrya/Carpinus, Ulmus, Quercus, and Fraxinus were present in very low amounts, and showed no long-term changes.
In Zone II (500-150 years ago), Picea PAR rapidly increased. P. strobus, Betula and Alnus pollen increased slightly. Tsuga and Cupressineae pollen decreased in this zone; this decrease in Tsuga continued the trend begun 900 years ago. A low, but consistent influx of $P$. banksiana/resinosa pollen suggests long-distance transport. Maxima and minima in the PAR curves were registered in all pollen types simultaneously (e.g. 350 or 500 years ago) and thus reflect sedimentological rather then pollendepositional events (see SWAIN, 1978).

In Zone III (150 years ago to A.D. 1974) non arboreal pollen (NAP) abruptly increased, as the landscape was disturbed by the activities of European settlement. Alnus increased and Populus pollen was consistently present for the first time in the past 2000 years. Pollen of several tree taxa increased, but the possibility of multiple annual laminations (see Appendix I) precludes detailed interpretation of these PAR values. Tsuga and Fagus pollen accumulation rates further decreased.

\section{BASIN POND}

The Basin Pond PAR diagram (Fig. 3), covering the past 1600 years prior to 1974 , was also divided into three zones. Changes in this diagram are broadly similar to those of Conroy Lake, although the PAR of the various taxa can be quite different. Tsuga, Fagus, and Quercus pollen, in particular, are more abundant in Basin Pond than at Conroy Lake.

Zone I (1600 to 500 years ago) was characterized by a high PAR of Tsuga and Fagus, and relatively low amounts of Pinus strobus and Quercus. Picea pollen amounts were low from 1600 to 1000 years ago, and slowly increased between 1000 and 500 years ago. As at Conroy Lake, pollen of the hardwoods - Ostrya/Carpinus, Ulmus, and Fraxinus - was never particularly abundant. In Zone II (500 to 150 years ago) Picea PAR continued to increase, reaching values of 1500 grains $/ \mathrm{cm}^{2} / \mathrm{yr}$. P. strobus and Quercus pollen in-

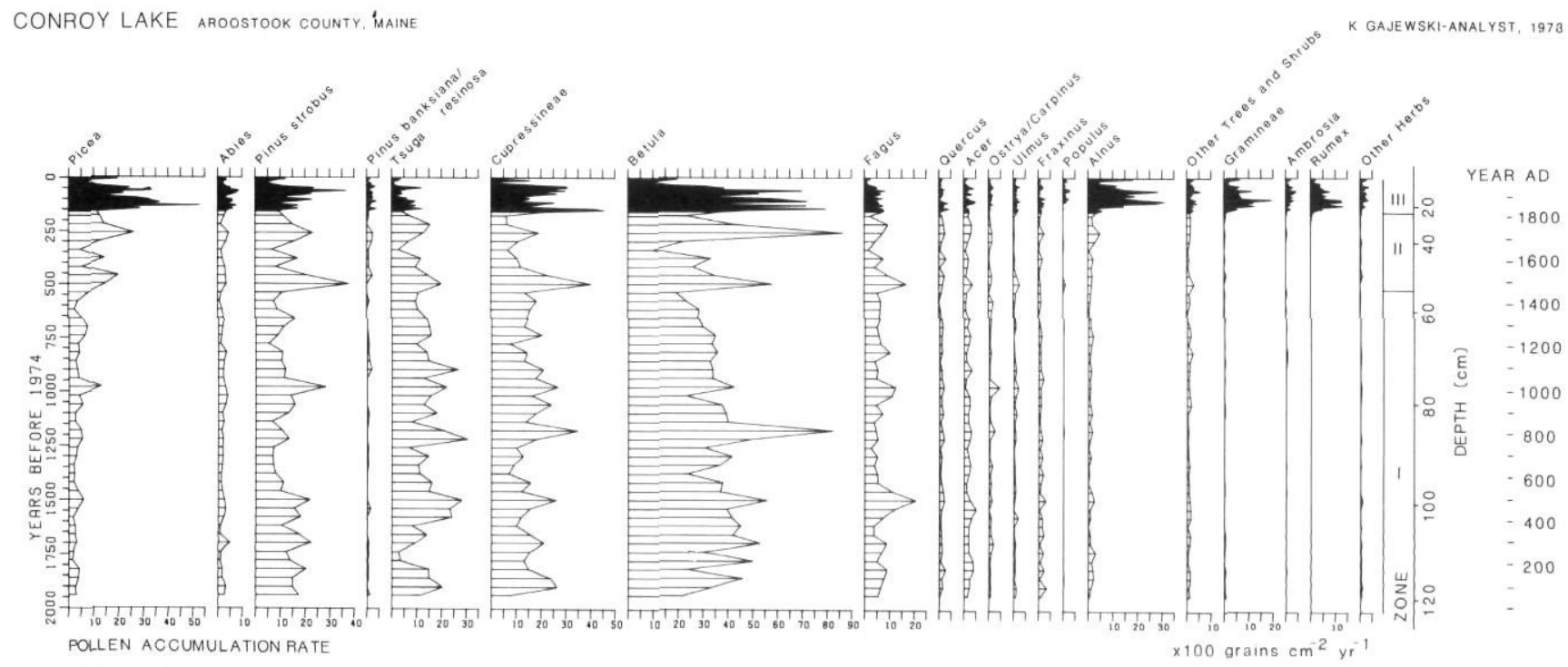

FIGURE 2. Pollen accumulation rate (PAR) diagram for Conroy Lake.

Diagramme de l'influx pollinique, Conroy Lake. 
TABLE

Pollen accumulation rates (grains/ $\mathrm{cm}^{2} /$ year) of taxa not included on the pollen diagrams

\begin{tabular}{|c|c|c|c|c|c|c|c|c|c|c|c|}
\hline $\begin{array}{l}\text { Years } \\
\text { before }\end{array}$ & Tilia & & Juglans & & Platanus & $\begin{array}{l}\text { Years } \\
\text { before }\end{array}$ & Tilia & & Juglans & & Platanus \\
\hline 1974 & & Carya & & Castanea & & 1974 & & Carya & & Castanea & \\
\hline \multicolumn{5}{|l|}{ CONROY LAKE } & \multicolumn{3}{|c|}{ BASIN POND } & \multirow{2}{*}{\multicolumn{3}{|c|}{59}} & \\
\hline 7 & & & 23 & & & 15 & & & & & \\
\hline 14 & & 20 & & & 20 & 25 & & 47 & & 94 & \\
\hline 35 & & 24 & & & & 35 & & & & 95 & \\
\hline 42 & 39 & & & & & 55 & 38 & 38 & & 38 & \\
\hline 49 & & & & & 59 & 65 & & 16 & 16 & 31 & 16 \\
\hline 77 & 48 & & & & & 75 & 10 & & & & \\
\hline 84 & & & & 42 & & 85 & & & & 88 & \\
\hline 91 & & & & & 24 & 95 & 50 & & & 101 & \\
\hline 105 & & & & 64 & & 115 & & & & & 63 \\
\hline 119 & & 53 & & & & 125 & & & & & 33 \\
\hline 133 & & & & 139 & 70 & 135 & & 68 & & & 34 \\
\hline 140 & & & & 24 & & 155 & 45 & & & & \\
\hline 147 & & & & 137 & & 185 & & 32 & 32 & 32 & \\
\hline 154 & & & & & 45 & 215 & & 48 & & 24 & \\
\hline 161 & & & 29 & & 29 & 255 & & 33 & & 99 & \\
\hline 180 & 18 & 18 & & & & 295 & & 54 & & & \\
\hline 220 & 28 & & & 55 & & 335 & 33 & 65 & & & \\
\hline 300 & & 29 & & & & 375 & & 25 & 25 & & \\
\hline 340 & & 17 & & & & 415 & & & & 38 & 38 \\
\hline 380 & & & 23 & & & 455 & & & & & 27 \\
\hline 460 & & & & 47 & & 495 & & & & 46 & 46 \\
\hline 500 & & & & 52 & & 535 & & 37 & & 37 & \\
\hline 580 & & & & 50 & 25 & 575 & 37 & & & 37 & \\
\hline 620 & & 18 & & & & 615 & & 33 & & 33 & \\
\hline 700 & & & 20 & 20 & 20 & 645 & & 31 & & 31 & \\
\hline 740 & & 26 & 26 & 26 & & 655 & 28 & & & 28 & 28 \\
\hline 780 & & & & 38 & & 695 & 32 & 63 & 32 & 63 & \\
\hline 900 & 35 & & & & & 735 & 23 & & 23 & 23 & \\
\hline 980 & & & 48 & & & 775 & 40 & & & 79 & \\
\hline 1020 & & & & & 31 & 815 & & 63 & & & 32 \\
\hline 1060 & 35 & 35 & & & & 895 & & 26 & & & \\
\hline 1180 & & & & 35 & & 935 & & 45 & & & 45 \\
\hline 1260 & & & & 20 & & 975 & & & & 76 & \\
\hline 1340 & & 24 & & 24 & 24 & 1015 & & 20 & & 20 & \\
\hline 1380 & & 18 & & & 18 & 1135 & & & & & 61 \\
\hline 1460 & & & & & 27 & 1055 & 26 & & & 26 & \\
\hline 1580 & & & 30 & 30 & 30 & 1095 & & & & 29 & \\
\hline 1620 & & & & & 25 & 1135 & & & & 31 & \\
\hline 1660 & & & & & 31 & 1175 & 41 & 41 & & & \\
\hline 1820 & & 32 & & & & 1255 & & & & 19 & 57 \\
\hline 1860 & & 28 & & 28 & 28 & 1295 & & 35 & & & \\
\hline \multirow[t]{3}{*}{1940} & & & & 22 & & 1335 & & 29 & & 15 & 15 \\
\hline & Populus & & & & & $\begin{array}{l}1375 \\
1415\end{array}$ & & $\begin{array}{l}46 \\
17\end{array}$ & 17 & 46 & 92 \\
\hline & & Picea & & & & 1455 & 26 & & 52 & 26 & 26 \\
\hline ELY LAKE & & & & & & $\begin{array}{l}1495 \\
1535\end{array}$ & 26 & 68 & 34 & 26 & 26 \\
\hline 50 & 181 & & & & & 1575 & 50 & 25 & & & \\
\hline 90 & 22 & 22 & & & & 1605 & & 63 & & 32 & \\
\hline 180 & & 29 & & & & & & & & & \\
\hline 300 & 30 & & & & & & Populus & & & & \\
\hline 540 & & 26 & & & & & & & & & \\
\hline 720 & 28 & & & & & CLEAR POND & & & & & \\
\hline 780 & & 22 & & & & 50 & 32 & & & & \\
\hline 860 & & 21 & & & & 250 & 26 & & & & \\
\hline 1080 & 26 & & & & & 290 & 77 & & & & \\
\hline 1180 & & 23 & & & & 730 & 35 & & & & \\
\hline 2050 & 28 & & & & & 810 & 78 & & & & \\
\hline 2210 & & 17 & & & & 890 & 24 & & & & \\
\hline
\end{tabular}


creased while Tsuga and Fagus decreased.

Zone III (150 years ago to the present) was characterized by a major increase in NAP. Unlike in the Conroy Lake pollen diagram, Alnus and Populus pollen did not greatly increase in this zone.

\section{CLEAR POND}

The Clear Pond PAR diagram was divided into four zones (Fig. 4). Level 1290 (years ago) was not plotted, as it had a total PAR value of 41,000 grains $/ \mathrm{cm}^{2} / \mathrm{yr}$ - four times that of the mean of the other samples. The percentages of this level were reasonable, however, and showed values in- termediate between those of the adjacent two levels.

Zone I (1890 to 1250 years ago) was characterized by low values of Picea pollen and relatively high accumulation rates of Tsuga and Fagus pollen. Pinus strobus remained low in this and the subsequent zone, while Betula pollen showed a slight long-term increase in this zone and in Zone II. Acer PAR were relatively high at Clear Pond, attaining values greater than 500 grains $/ \mathrm{cm}^{2} / \mathrm{yr}$ in several sections of the diagram. Acer remained constant at these relatively high values throughout the past 1600 years at this site.

Picea PAR increased abruptly between 1200 and 1300 years ago. In Zone II (1250 to 500 years ago), Picea PAR re-

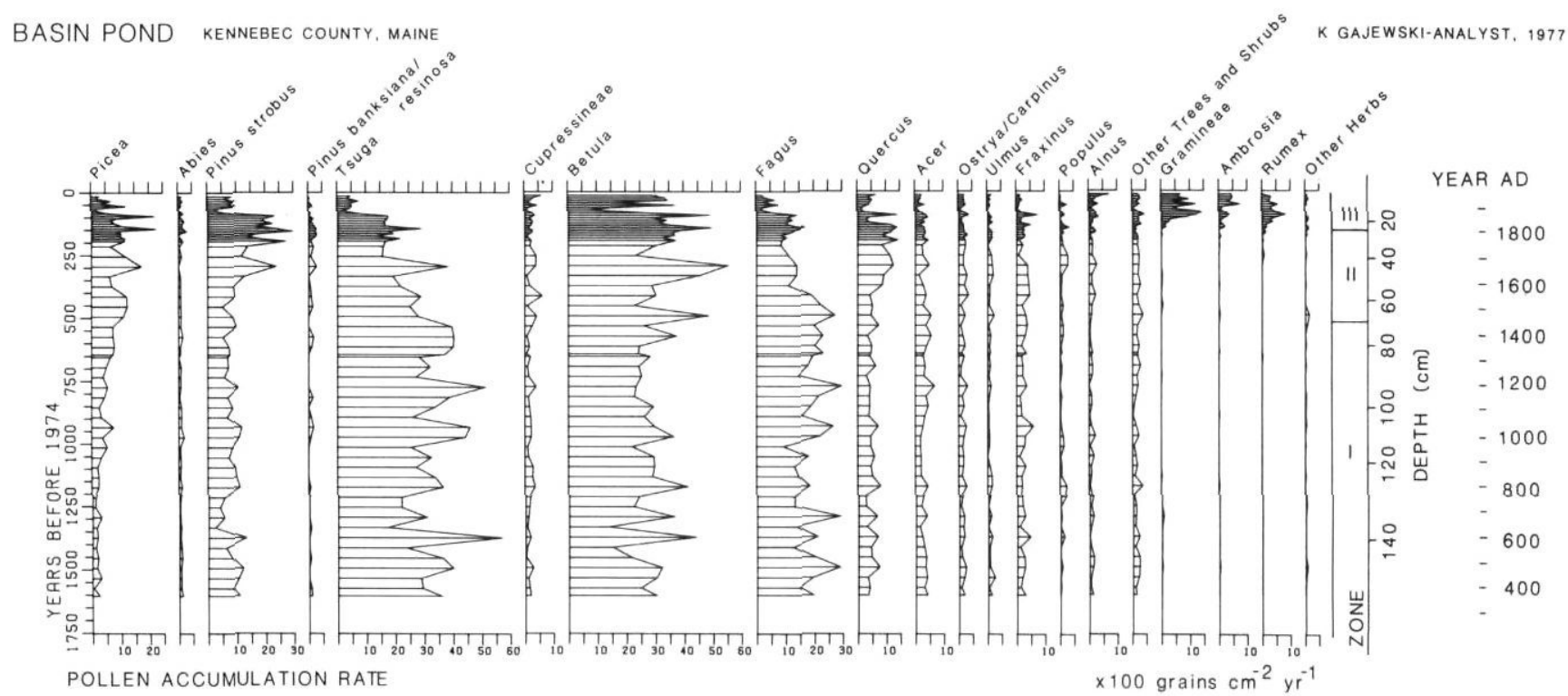

FIGURE 3. Pollen accumulation rate (PAR) diagram for Basin Pond.

Diagramme de l'influx pollinique, Basin Pond.

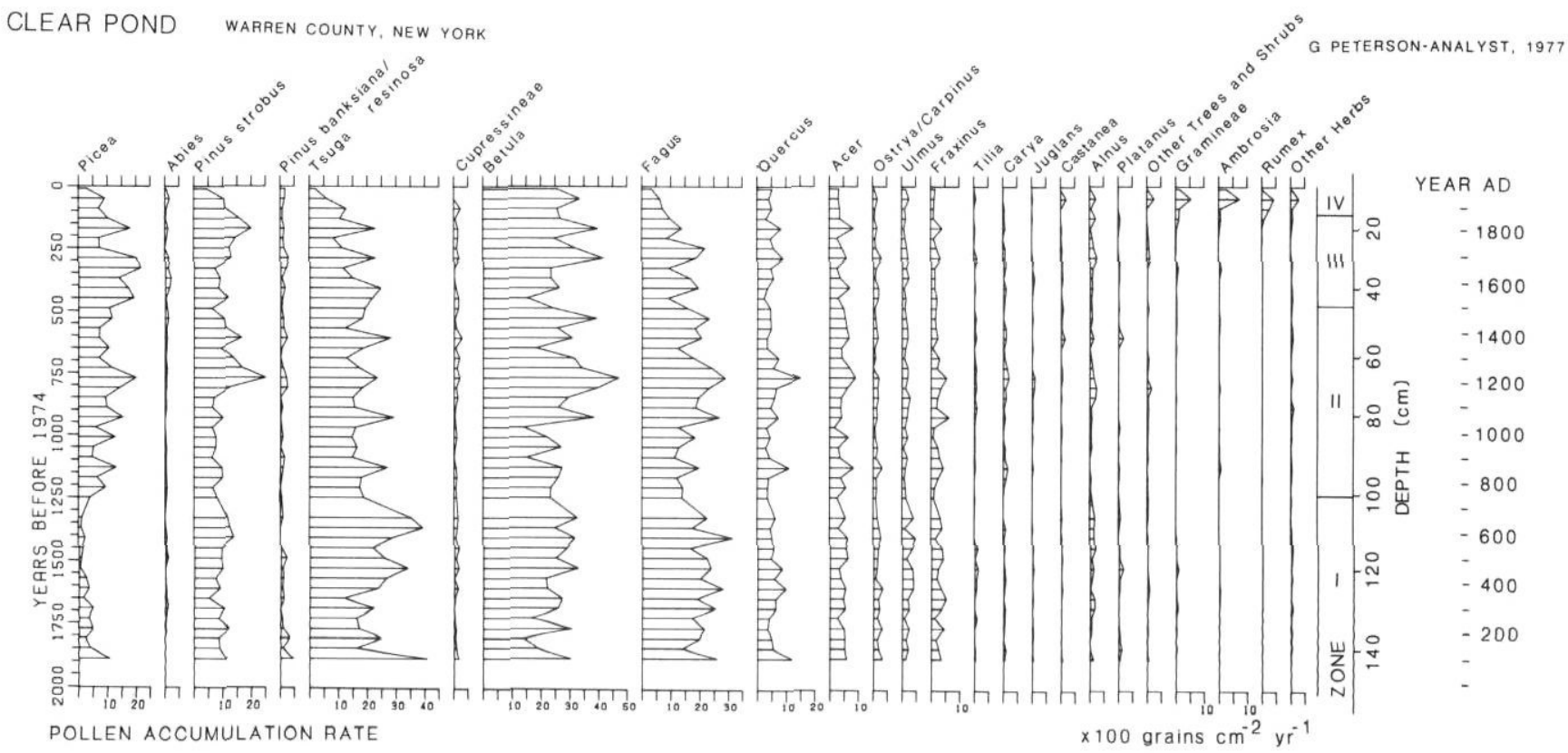

FIGURE 4. Pollen accumulation rate (PAR) diagram for Clear Pond.

Diagramme de l'influx pollinique, Clear Pond. 
mained between 1000 and 2000 grains $/ \mathrm{cm}^{2} / \mathrm{yr}$. Tsuga and Fagus pollen decreased. In Zone III (500 to 100 years ago) Picea pollen again increased, while Tsuga and Fagus steadily declined. Abies pollen was consistently present in Zone III. Most pollen taxa were little changed from Zone II. Although never particularly abundant, Ostrya/Carpinus, UImus, and Fraxinus were slightly less abundant in Zone III than in Zone I.

Zone IV (100 years to the present) is the European settlement period. NAP and Betula increased, while most tree pollen decreased in this zone.

\section{ELY LAKE}

The pollen accumulation rate diagram of Ely Lake (Fig. 5) was divided into four zones. Ely Lake is located to the south of the other three lakes, and there were no Abies and only occasional grains of Picea pollen in the sediment (Table I). Pollen types from trees of the southern deciduous forest, e.g. Carya, Juglans and Castanea, are important components of this diagram, and Quercus pollen is more abundant than at the other sites. Tsuga pollen is more abundant than at either Conroy Lake or Clear Pond, and has values comparable to those at Basin Pond.

In Zone I (2370 to 900 years ago) Pinus strobus, Quercus, and Castanea pollen steadily decreased, while Tsuga, Betu$l a$, and Fagus increased. The similarities of the profiles of Tsuga, Fagus and Betula in this diagram suggest that the dominant species of Betula at this site was Betula lutea.
In Zone II (900 to 400 years ago) Castanea PAR increased, reaching a maximum value of nearly 2000 grains $/ \mathrm{cm}^{2} / \mathrm{yr} 700$ years ago, and subsequently decreased in the younger portion of the zone. Quercus and $P$. strobus pollen increased in this zone, while Tsuga, Betula, and Fagus decreased. These trends reversed in Zone III (400 to 150 years ago) with most pollen types approaching values comparable to those at the top of Zone I. Alnus pollen was consistently present at low amounts in Zone III. In Zone IV (150 years ago to the present) NAP increased while most arboreal pollen decreased in abundance.

\section{DISCUSSION}

In making inferences about the vegetation from these pollen diagrams, we were guided by the interpretations of WEBB et al. (1983) relating pollen to vegetation in southern Québec. At Conroy Lake a mixture of hemlock-hardwood forests and spruce-fir forests was regionally important in the late Holocene. The pollen sequence at Conroy Lake suggests a long term replacement of hardwoods by boreal forest elements. In Zone I Tsuga trees were abundant in the landscape around Conroy Lake, and remained important in the area in Zone II. By the time of European settlement, Picea trees had increased in the region. MOTT (1975) showed the beginnings of this increase in Picea in western New Brunswick, but the upper portions of some of his cores were truncated or the increase in Picea was undated. At Conroy Lake, quantities of Pinus strobus and Quercus pollen were low, and at these values, could have been blown in from a distance. P. strobus trees, however, were

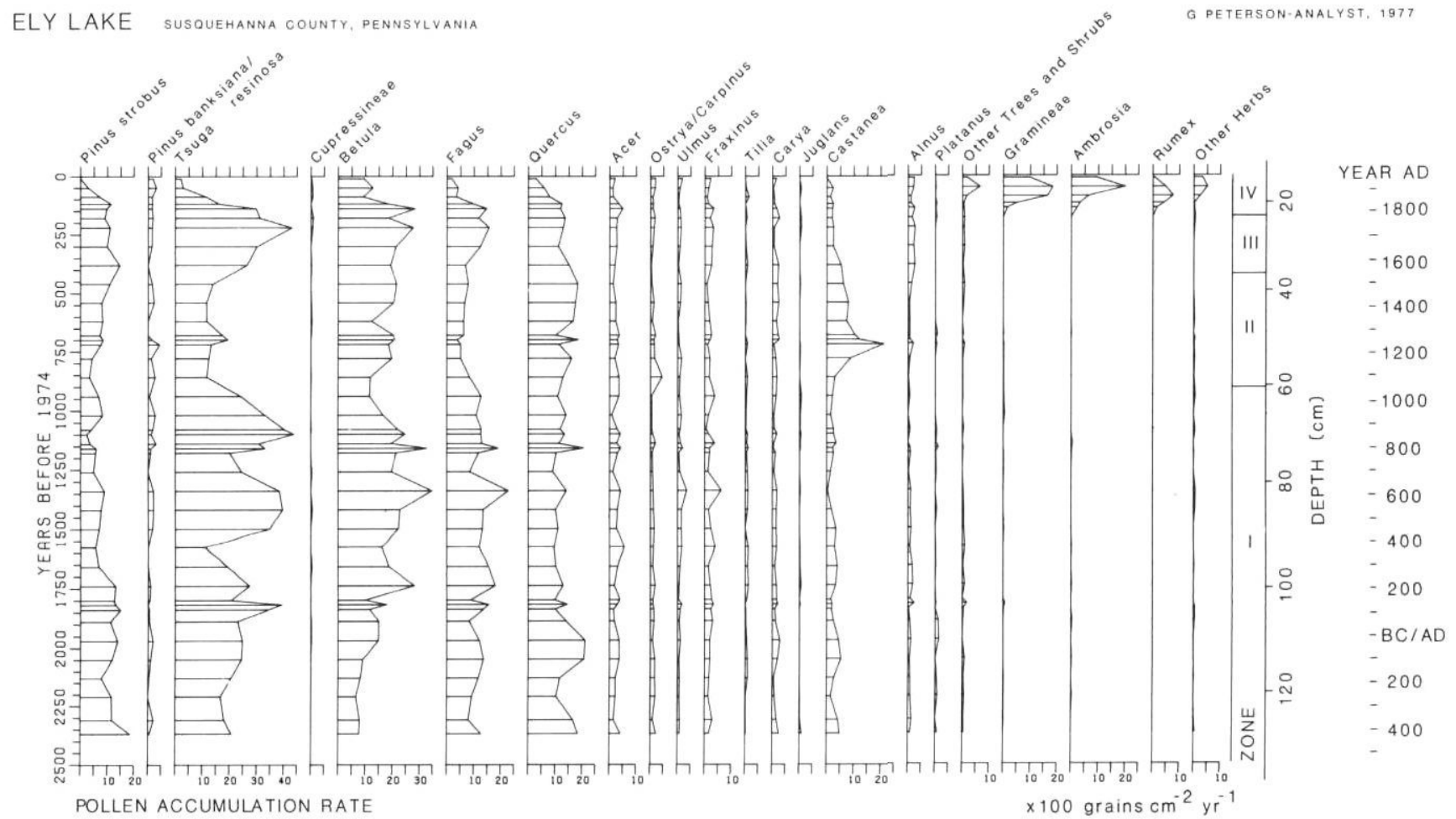

FIGURE 5. Pollen accumulation rate (PAR) diagram for Ely Lake.

Diagramme de l'influx pollinique, Ely Lake. 
probably present in low densities in the immediate area, as this species frequently reproduces in gaps in the forests following disturbance (HIBBS, 1982). Throughout the past 1600 years, there remained significant numbers of Betula trees in the landscape. Fagus and Acer pollen were relatively constant at low levels, although both species were probably relatively abundant on the landscape. Abies pollen amounts were low, but these more or less constant values in the past 2000 years indicate that Abies trees were present in the area around Conroy Lake, because at the present time Picea rubens and Abies balsamea are the dominant trees over the whole landscape in northwestern Maine, while hardwoods are limited to better soils (OOSTING and REED, 1944). To the east, in western New Brunswick, hardwoods such as Fagus grandifolia and Acer spp. are equally important in the vegetation as the softwoods, with the softwoods more important at lower elevations and the hardwoods showing the reverse trend (POWELL, 1984). The area around Conroy Lake has low relief, and today there is agriculture within $100 \mathrm{~m}$ of the lake, but all of these species, and others such as Betula papyrifera and Populus tremuloides are found in the immediate area (Swain, personal observation). The pollen diagram suggests that the softwoods have increased in the recent past at the expense of the hardwoods and Tsuga. Today, there are very few Tsuga trees around the lake (Swain, personal observation). ROGERS (1978) suggested that the low values of Tsuga in many forests today was due to disturbance of the forests associated with European settlement, but this decrease had begun prior to settlement. Similar observations have been made for Fagus (GAJEWSKI, 1983 ; BENNETT, 1985).

At Basin Pond and Clear Pond, a mesic hemlockhardwood forest with increasing Picea was prevalent during the late Holocene. At Basin Pond, the values of pollen influx suggest abundant numbers of Tsuga, Fagus, and Acer trees in the vegetation, and the presence of Quercus and Betula. Even after the transition to Zone 2, Tsuga and Fagus remained abundant in the vegetation, and Quercus became a more important component of the forest. $P$. strobus never attained significant numbers. Although Picea pollen increased throughout the time period, there are more rapid increases around 1050 and 500 years ago. The first increase at 1050 years ago was followed by an increase in Acer and Tsuga, while the second increase at 500 years ago was accompanied by a decrease in Tsuga, Fagus and Acer and an increase in Quercus and Pinus pollen accumulation rates. However, Picea trees were never particularly abundant in the landscape. At the present time, the range of Picea glauca extends approximately to Basin Pond and $P$. rubens extends a little further to the south (FOWELLS, 1965). Interpretation of the Basin Pond core suggests that there has been a relatively recent extension southward in the range of one or both of these two species. North of Basin Pond, along the Maine-Québec border, MOTT (1977) found that a Picea-Betula zone replaced an earlier Acer-Fagus zone. The date of this transition was about 1500 to 2000 years ago, and generally coincides with the entire sequence from $\mathrm{Ba}$ sin Pond presented here. RICHARD (1978) found an increase in Picea mariana in southern Québec at this time.
Although we did not separate the Picea pollen into species in our study, none of the lakes has a bog surrounding it (SWAIN, personal observation) and thus the species comprising the increase in this region was probably also $P$. glauca or $P$. rubens. In northern New Hampshire, Picea pollen was at low levels around 3000 years ago, and quickly increased to greater than $10 \%$ at 2000 years ago. Tsuga and Fagus pollen decreased at this time, while few other types showed any long term changes (LIKENS and DAVIS, 1975).

At Clear Pond in Zones I and II, Tsuga, Fagus and Acer trees were abundant components of the forests in the region, while neither $P$. strobus nor Quercus were particularly significant. Tsuga and Fagus trees are characteristically found in more mesic sites and in older forests in the Lake George region (NICHOLSON et al., 1979) while $P$. strobus and Quercus are early successional species in the Catskills (McINTOSH, 1972). Values of Acer pollen are quite high, and indicate the importance of Acer trees in the forest around Clear Pond ; Acer pollen values (which amount to 3$7 \%$ ) were greater than those of the "érablière" of southern Québec (RICHARD, 1976). Picea pollen increased in importance, particularly in Zone III. In northern New York (Brandreth Bog), OVERPECK (1985) showed a Picea pollen increase to over $5 \%$ at around the same time as at Clear Pond (between 1000 and 1500 YBP at Brandeth Bog), and a decrease in Tsuga and Fagus pollen in the past 1000 years. Accumulation rates at Brandreth Bog are greater and more variable than those at Clear Pond, probably because of a sediment change at Brandreth Bog. The PAR results from Clear Pond may be more representative of true changes in pollen production during this time period, because there are no sediment changes accompanying the pollen changes.

At Ely Lake, a hemlock-hardwood forest mixed with southern deciduous taxa (Quercus, Castanea, Carya, etc.) was present in the late Holocene, while the relative importance of these elements changed over time. The values of PAR at Ely Lake indicate significant amounts of Tsuga and Fagus trees in the landscape. These species, and other taxa such as Acer, Tilia, Fraxinus, Ulmus, Quercus, Betula, and Populus are today present in the immediate vicinity of the lake (Swain, personal observation). Castanea and Quercus were consistently present in the region, especially during the time represented by Zone III. In southeastern Pennsylvania and New Jersey, Quercus species, in combination with Carya (and Castanea prior to this century), are found on drier sites, while Tsuga and the northern hardwoods are found on more mesic sites (KEEVER, 1973; ROBICHAUD and BUELL, 1973; BUELL et al., 1966; OHMAN and BUELL, 1968). Tsuga is sensitive to drought and disturbance (ROGERS, 1978). The decline in Tsuga pollen between 1100 and 500 years ago suggests that there was a significant dry period in this interval.

The abundant taxa in all four cores show consistent changes in PAR values that occur quickly (within a couple hundred years) or persist for several centuries. In a previous study (GAJEWSKI et al., 1985) we suggested that rapid changes in the abundance of pollen in laminated sediments represent real changes in the forest. We can now compare 
the pollen chronologies at the four sites and attempt to infer possible causes of the changes. If an increase or decrease in a particular pollen taxon occurs simultaneously over a large area, this suggests a climatic cause.

The pollen sequences at Conroy Lake, Basin Pond and Clear Pond are broadly similar. These diagram specify in more detail the late Holocene increase in Picea and other boreal forest taxa and the decrease of taxa of the coniferhardwood forest along the southern border of the boreal forest that has been identified at numerous sites in northeastern United States and southeastern Canada (BERNABO and WEBB, 1977 ; WEBB et al., 1983 ; GAUDREAU and WEBB ; 1985). The pollen types that can be easily correlated between sites (e.g. Picea) are those that illustrate biomelevel changes and which increase from negligible values in the middle Holocene to significant portions of the pollen rain by the present time. Alternatively, large-scale coherent changes can be seen in pollen types that reach their maximum values in this region (Tsuga and Fagus). The similarities in the profiles of these taxa indicate regional changes in the vegetation, although the particular sequence depends on the location. Picea increased at the northern sites while Tsuga and Fagus decreased, with more rapid changes occurring at 500 years ago and perhaps around 1200 to 1000 years ago. At these times, Tsuga and Fagus first decreased and then increased, while Quercus and Castanea showed the opposite trend at Ely Lake.

Many of the pollen types do not show patterns that can be correlated between sites. Pollen of some hardwood genera - Ostrya/Carpinus, Ulmus, Fraxinus, Tilia and Acer - were present in such low amounts that regional patterns cannot be determined. Other types - Abies, Carya, Castanea and Juglans - are only present in one or two diagrams, and thus regional patterns cannot be traced.

Betula, Quercus, and Pinus strobus pollen stratigraphy is more difficult to interpret for several reasons. Betula and Quercus pollen types include several species with different ecological tolerances and behaviours. All three taxa are prolific pollen producers, and at the values present in these cores, significant amounts could have been blown in from elsewhere. Quercus PAR increased at Basin Pond but showed no change at Clear Pond or Conroy Lake 400 years ago; Quercus PAR decreased at Ely Lake at this time. P. strobus values were relatively low at all sites; WEBB et al. (1983) indicate that $15 \%$ of the pollen can be blown in from long distance. $P$. strobus increased between 500 years ago and settlement at Conroy Lake, Basin Pond and Clear Pond, while it decreased at Ely Lake. Betula pollen amounts indicate significant values at Basin and Conroy Lakes, but not necessarily at Clear and Ely Lakes. This may be due to the relatively greater importance of $B$. papyrifera trees at the Maine sites, while $B$. lutea trees were more important at the middle Atlantic sites. Because of the differences in the ecology of these species and the presence of other species of Betula in northeastern United States, these profiles are difficult to compare between sites. Interpretation of climatic change from these pollen diagrams is discussed in more detail in GAJEWSKI (1983).
Comparison of the timing of the more rapid changes in the four pollen records provides further evidence of the importance of late Holocene climatic changes on the vegetation in this region. More rapid changes in the pollen curves were clustered between 500 and 400 years ago and between 1200 and 900 years ago. Other late Holocene fossil data also show transitions at these times (SWAIN, 1978). The broad synchroneity in the times of rapid changes, and the similarity of many of the pollen profiles of the four sites suggests the influence of century-scale climate changes on the vegetation of this region.

These cores provide further information about the complex history of several species in the forests of eastern North America. A dense array of closely-samples and welldated pollen sites could provide new information about the dynamics of vegetation and the factors affecting tree species at many time scales.

\section{ACKNOWLEDGMENTS}

This work was supported by NSF Grants ATM-8111455 and ATM-8219079. We would like to thank R. Steventon for assistance in the field and for processing the pollen samples. J. Kutzbach, T. Webb, and M. Winkler read various versions of the manuscript.

\section{REFERENCES}

BARRETT, J.W., ed. (1980) : Regional silviculture of the United States, Second ed, J. Wiley and Sons, New York, 551 p.

BENNETT, K.D. (1985): The spread of Fagus grandifolia across eastern North America during the last 18,000 years, Journal of Biogeography, Vol. 12, p. 147-164.

BERNABO, J.C. and WEBB III, T. (1977) : Changing patterns in the Holocene pollen record of northeastern North America: a mapped summary, Quaternary Research, Vol. 8, p. 64-96.

BUELL, M.F., LANGFORD, A.N., DAVIDSON, D.W. and OHMAN, L.F. (1966) : The upland forest continuum in northern New Jersey, Ecology, Vol. 47, p. 416-432.

BRUGAM, R.B. (1978) : Human disturbance and the historical development of Linsley Pond, Ecology, Vol. 59, p. 19-36.

CRAIG, A.J. (1972) : Pollen influx to laminated sediments : a pollen diagram from northeastern Minnesota, Ecology, Vol. 53, p. $46-57$.

DAVIS, M.B. (1969): Climatic changes in southern Connecticut recorded by pollen deposition at Rogers Lake, Ecology, Vol. 50, p. $409-422$.

(1983) : Holocene vegetational history of eastern United States, p. 166-181, in Late-Quaternary environments of the United States, Vol. 2, The Holocene, H.E. Wright (ed.), University of Minnesota Press, Minneapolis, $277 \mathrm{p}$.

DAVIS, M.B., SPEAR, R.W., and SHANE, L.C.K. (1980) : Holocene climate of New England, Quaternary Research, Vol. 14, p. $240-250$.

DAVIS, R.B. (1967) : Pollen studies of near-surface sediments in Maine Lakes, p. 143-173, in Quaternary paleoecology, E.J. Cushing and H.E. Wright, Jr. (eds), Yale University Press, New Haven, $433 p$. 
DAVIS, R.B., BRADSTREET, T.E., STUCKENRATH, R. Jr., and BORNS, H.W. Jr. (1975) : Vegetation and associated environments during the past 14,000 years near Moulton Pond, Maine, Quaternary Research, Vol. 5, p. 435-465.

DAVIS, R.B. and NORTON, S.A. (1978) : Paleolimnological studies of human impact on lakes in the United States, with emphasis on recent research in New England, Polskie Archiwum Hydrobiologii, Vol. 25, p. 99-115.

DIGERFELDT, B., BATTARBEE, R.W. and BENGTSSON, L. (1975) : Report on annually laminated sediment in Lake Jarlasjon, Nacka, Stockholm, Geologiska Foreningens i Stockholm Forhandlingar, Vol. 97, p. 29-40.

FAEGRI, K. and IVERSEN, J. (1975): Textbook of pollen analysis, Third Revised Edition, Hafner Press, New York, 295 p.

FOBES, C.B. (1944) : Path of the settlement and distribution of population of Maine, Economic Geography, Vol. 20, p. 65-69.

FOWELLS, H.A. (1965) : Silvics of forest trees of the United States, USDA Forest Service Agricultural Handbook No. 271, 762 p.

GAJEWSKI, K. (1983) : On the interpretation of climatic change from the fossil record: climatic change in central and eastern United States over the past 2000 years estimated from pollen data, $\mathrm{PhD}$ thesis, University of Wisconsin-Madison, $212 \mathrm{p}$.

GAJEWSKI, K., WINKLER, M.G. and SWAIN, A.M. (1985) : Vegetation and fire history from three lakes with varved sediments in northwestern Wisconsin (U.S.A.), Review of Palaeobotany and Palynology, Vol. 44, p. 277-292.

GAUDREAU, D.C. and WEBB III, T. (1985): Late-Quaternary pollen stratigraphy and isochrone maps for the northeastern United States, p. 247-280, in Pollen records of Late-Quaternary North American sediments, V.M. Bryant, Jr. and R.G. Holloway (eds), American Association of Stratigraphic Palynologists, Dallas, $426 \mathrm{p}$.

HIBBS, D.E. (1982) : White pine in the transition hardwood forest, Canadian Journal of Botany, Vol. 60, p. 2046-2053.

JOHNSTON, S.E. (1981) : A comparison of dating methods in laminated lake sediments in Maine, M.S. thesis, University of Maine at Orono, $79 \mathrm{p}$.

KEEVER, C. (1973): Distribution of major forest species in southeastern Pennsylvania, Ecological Monographs, Vol. 43, p. 303-327.

LIKENS, G.E. and DAVIS, M.B. (1975) : Post-glacial history of Mirror Lake and its watershed in New Hampshire, U.S.A. : an initial report, Verhandlungen der Internationalen Vereinigung fuer Theoretische und Angewandte Limmologie, Vol. 19, p. 982-993.

LULL, H.W. (1968) : A forest atlas of the northeast, USDA Forest Service, Northeastern Forest Experiment Station, Upper Darby, Pennsylvania, $46 \mathrm{p}$.

McINTOSH, R.P. (1972) : Forests of the Catskill Mountains, New York, Ecological Monographs, Vol. 42, p. 143-161.

MAHER Jr., L.J. (1981) : Statistics for microfossil concentration measurements employing samples spiked with marker grains, Review of Palaeobotany and Palynology, Vol. 32, p. 153-191.

MOTT, R.J. (1975) : Postglacial history and environments in southwestern New Brunswick, Proceedings. Nova Scotia Institute of Science, Vol. 27 Supplement 3, p. 67-82.

(1977) : Late-Pleistocene and Holocene palynology in southeastern Québec, Géographie physique et Quaternaire, Vol. 31, p. 139-149.
NICHOLSON, S.A., SCOTT, J.T., and BREISCH, A.R. (1979) : Structure and succession in the tree stratum at Lake George, New York, Ecology, Vol. 60, p. 1240-1254.

OHMAN, L.F. and BUELL, M.F. (1968): Forest vegetation of the New Jersey highlands, Bulletin of the Torrey Botanical Club Vol. 95, p. 287-298

OOSTING, H.J. and REED, J.F. (1944) : Ecological composition of pulpwood forests in northwestern Maine, American Midland Naturalist, Vol. 31, p. 182-210.

OVERPECK, J.T. (1985) : A pollen study of a late Quaternary peat bog, south-central Adirondack Mountains, New York, Geological Society of America Bulletin, Vol. 96, p. 145-154.

POWELL, G.R. (1984) : Forest cover on two watersheds of the Nashwaak Experimental Watershed Project in west-central New Brunswick, Naturaliste canadien, Vol. 111, p. 31-44.

RENBERG, I. (1976): Annually laminated sediments in Lake Rudetjarn, Medelpad province, northern Sweden, Geologiska Foreningens i Stockholm Forhandlingar, Vol. 98, p. 355-360.

RICHARD, P. (1976): Relations entre la végétation actuelle et le spectre pollinque au Québec, Naturaliste Canadien, Vol. 103 , p. $53-66$

(1977): Histoire post-wisconsinienne de la végétation du Québec méridional par l'analyse pollinique, Service de la Recherche, Direction générale des forêts, ministère des Terres et Forêts du Québec, Tome 1, 312 p., Tome 2, 142 p.

(1978) : Histoire tardiglaciaire et postglaciaire de la végétation au Mont Shefford, Québec, Géographie physique et Quaternaire, Vol. 32, p. 81-93

ROGERS, R.S. (1978) : Forests dominated by hemlock (Tsuga canadensis) : distribution as related to site and postsettlement history, Canadian Journal of Botany, Vol. 56, p. 843-854.

ROBICHAUD, B. and BUELL, M.F. (1973) : Vegetation of New Jersey, Rutgers University Press, New Jersey, $340 \mathrm{p}$.

SAARNISTO, M. (1985) : Long varve series in Finland, Boreas, Vol. 14, p. 133-137

SAARNISTO, M., HUTTUNEN, P., and TOLONEN, K. (1977) : Annual lamination of sediments in Lake Lovojarvi, southern Finland, during the past 600 years, Annales Botanici Fennici, Vol. 14, p. 35-45.

SIMOLA, H. and TOLONEN, K. (1981): Diurnal laminations in the varved sediment of Lake Lovojarvi, south Finland, Boreas, Vol. 10, p. $19-26$

SWAIN, A.M. (1973): A history of fire and vegetation in northeastern Minnesota as recorded in lake sediments, Quaternary Research, Vol. 3, p. 383-396.

(1978) : Environmental changes during the past 2000 years in north-central Wisconsin : analysis of pollen, charcoal, and seeds from varved lake sediments, Quaternary Research, Vol. 10, p. $55-68$.

TOLONEN, K. (1980): Comparison between radiocarbon and varve dating in Lake Lampellonjarvi, south Finland, Boreas, Vol. 9, p. 11-19.

TOLONEN, M. (1978) : Palaeoecology of annually laminated sediments in Lake Ahvenainen, S. Finland. II. Comparison of dating methods, Annales Botanici Fennici, Vol. 15, p. 209-222.

VUORINEN, J. (1978) : The influence of prior land use on the sediments of a small lake, Polskie Archiwum Hydrobiologii, Vol. 25, p. 443-451. 
WEBB III, T., RICHARD, P.J.H., and MOTT, R.J. (1983) : A mapped history of Holocene vegetation in southern Québec, p. 273-366, in Climatic Change in Canada 3, C.R. Harington (ed.), Syllogeus No. 49, National Museum of Natural Sciences, Ottawa.

WESTVELD, M., ed. (1956) : Natural forest vegetation zones of New England, Journal of Forestry, Vol. 54, p. 332-338.
WHITEHEAD, D.R. (1979) : Late-Glacial and Postglacial vegetational history of the Berkshires, western Massachusetts, Quaternary Research, Vol. 12, p. 333-357.

WRIGHT, H.E., Jr. (1980) : Cores of soft lake sediments, Boreas, Vol. 9, p. 107-114.

\section{APPENDIX I \\ CORE CHRONOLOGIES}

We have assumed in this study that the laminations present in these cores are annual. Although we have not analyzed the laminations in detail, there are several lines of evidence that suggest that laminations found in small and deep lakes in temperate regions are annual. Several investigations in Scandinavia and eastern North America (e.g. CRAIG, 1972 ; DIGERFELDT et al., 1975; RENBERG, 1976 ; SAARNISTO, 1985 ; SAARNISTO et al., 1977; TOLONEN, 1980 ; TOLONEN, 1978) have demonstrated the annual nature of laminations such as those analyzed in this study (but see SIMOLA and TOLONEN, 1981). In these and other laminated lakes (e.g. see SWAIN, 1978 ; GAJEWSKI et al., 1985), the European settlement horizon, an increase in non-arboreal pollen, dates at approximately the time documented by historical records, except for Conroy Lake (see below). In a previous study, we analyzed the pollen sequences from three lakes within one $\mathrm{km}$ of each other (GAJEWSKI et al., 1985). The pollen sequences for the three lakes were similar, suggesting a regular accumulation of sediment.

Conroy Lake date correction

After the pollen diagram for Conroy Lake was completed and plotted, the non-arboreal pollen rise (Zone III of Fig. 2), which in the northeast dates the arrival of European settlement (DAVIS, 1967), was dated at 225 "varve years ago" (AD 1740). However, FOBES (1944) determined that by the 1820's there were only a few settlements in Aroostook County; the major period of settlement didn't occur until after 1834, when the Bangor-Houlton military road was completed. Since the increase in NAP was so distinct and included pollen types such as Rumex, which were never present in the diagram prior to settlement, it was realized that there was some error in the lamination counts in the uppermost sediments. Consequently, the NAP zone (Zone III) base was set at 150 years ago. In all calculations and subsequent analysis on this core, we assumed that the uppermost samples contained seven years rather than ten years. No correction was applied below the settlement horizon, where the laminations were more distinct and easily counted compared to those above the horizon.

Several lines of reasoning contribute to the decision to correct only the uppermost 150 years. The uppermost sediment of lakes is usually flocculant and the most easily disturbed when the sampler penetrates the sediment. Experience indicates that this is the most difficult portion of the core to count. European settlement, which is a major disturbance in North American watersheds, has frequently altered the geochemistry of lakes (DAVIS and NORTON, 1978; BRUGAM, 1978), which could affect varve sedimentation. VUORINEN (1978) found changes in varve sedimentation following the introduction of agriculture in eastern Finland, although he still found only one varve deposited per year.

Subsequent to the analyses reported here, JOHNSTON (1981) independently determined multiple laminations in Conroy Lake for at least the past 60 years. He used several methods of dating the cores, including stratigraphic markers, ${ }^{230} \mathrm{~Pb}$ and ${ }^{137} \mathrm{Cs}$. He found indications of agriculture in the core sediment chemistry. The watershed of Conroy Lake is more disturbed than most of the other lakes used in this study (Swain, personal observation; see also JOHNSTON, 1981). Thus it seems valid to correct the uppermost dates, but whether this is true for the sediment further down is as yet unknown. 